See discussions, stats, and author profiles for this publication at: https://www.researchgate.net/publication/343658250

Smart urbanism and smart citizenship: The neoliberal logic of 'citizenfocused' smart cities in Europe

Article in Environment and Planning C Politics and Space · August 2019

DOI: 10.1177/0263774X18806508\#_i13

CITATIONS

32

2 authors, including:

Rob Kitchin

National University of Ireland, Maynooth

313 PUBLICATIONS 16,404 CITATIONS

SEE PROFILE

Some of the authors of this publication are also working on these related projects:

Project Haptic Soundscapes View project

Project The Programmable City View project
READS

264 


\title{
Smart urbanism and smart citizenship: The neoliberal logic of 'citizen-focused' smart cities in Europe
}

EPC: Politics and Space 2019, Vol. 37(5) 813-830

(C) The Author(s) 2018

Article reuse guidelines: sagepub.com/journals-permissions DOI: I0.I I77/0263774X 18806508 journals.sagepub.com/home/epc

@SAGE

\section{Paolo Cardullo and Rob Kitchin (1)}

Maynooth University, Ireland

\begin{abstract}
This paper examines the neoliberal ideals that underpin participation and citizenship in the smart city and their replication mechanisms at the European level, particularly focusing on the work of the European Innovation Partnership for Smart Cities and Communities. The research consisted of three levels of data generation and analysis: a discourse analysis of policy documents and project descriptions of the $6 \mathrm{I}$ Commitments in the European Innovation Partnership for Smart Cities and Communities 'citizen-focus' cluster; interviews with a dozen stakeholders working on citizen engagement in a small sample of European Innovation Partnership for Smart Cities and Communities flagship projects; and twenty interviews with city officers and corporate exhibitors at the 2017 Smart City Expo and World Congress. We contend that smart cities as currently conceived enact a blueprint of neoliberal urbanism and promote a form of neoliberal citizenship. Supra-national institutions like the European Innovation Partnership for Smart Cities and Communities act at a multi-scalar level, connecting diverse forms of neoliberal urbanism whilst promoting policy agendas and projects that perform neoliberal citizenship in the spaces of the everyday. Despite attempts to recast the smart city as 'citizen-focused', smart urbanism remains rooted in pragmatic, instrumental and paternalistic discourses and practices rather than those of social rights, political citizenship, and the common good. In our view, if smart cities are to become truly 'citizen-focused', an alternative conception of smart citizenship needs to be deployed, one that enables an effective shift of power and is rooted in the right to the city, entitlements, community, participation, commons, and ideals beyond the market.
\end{abstract}

\section{Keywords}

Citizenship, smart cities, smart citizens, neoliberalism, European Union

\section{Corresponding author:}

Rob Kitchin, Maynooth University, lontas Building, North Campus, Maynooth, Kildare, Ireland.

Email: rob.kitchin@mu.ie 


\section{Introduction}

Although smart city initiatives and technologies are implemented at the urban/local scale, their circulation and diffusion are strongly shaped by institutions operating at a wider scale (regional authorities, national states, supra-national bodies). In this paper, we explore how the smart city policies, programmes and initiatives of the European Commission (EC) actively (re)produce a neoliberal conception of citizenship and participation through mechanisms of funding allocation, the application of scaling and replication techniques, and mobile policy formation (Lombardi and Vanolo, 2015). In particular, we show how under the European Innovation Partnership for Smart Cities and Communities (EIP-SCC) active forms of marketization have been taking place, with assemblages of neoliberal governance able to form and move swiftly through diverse cities across Europe and at a multiple scales, promoting a model of participation that is rooted in pragmatic, instrumental and paternalistic discourses and practices. This configuration presents neoliberalism as a more or less coherent ideology, rationality, policy agenda, and structural process that operates at the urban, neighbourhood and individual scales, and at the scale of intra-city collaboration at European and national levels (Brenner and Theodore, 2002; Brenner et al., 2010; Rossi, 2017). The multi-scalar perspective on neoliberal governance we adopt is made more relevant by the current phase of austerity politics that forces cities, deprived of autonomous spending capacity, to compete against each other in order to attract supra-national investments (Peck, 2012).

Wendy Brown (2016: 3) notes that, '[n] eoliberalism construes subjects as market actors everywhere, but in which roles - Entrepreneur? Investor? Consumer? Worker?' In our recent evaluation of smart city participation in Dublin, we identified 16 'smart citizen' roles, demonstrating that most of these are rooted in what Arnstein (1969) termed 'tokenism' and 'non-participation' (Cardullo and Kitchin, 2019). We noted that citizens occupy a largely passive role, with companies and city administrations performing forms of civic paternalism (deciding what's best for citizens) and stewardship (delivering on behalf of citizens). As other scholars have started to highlight with regards to a variety of smart city contexts (e.g., Cowley et al., 2018; Datta, 2018; Foth et al., 2015; Gabrys, 2014; McLaren and Agyeman, 2015; March and Ribera-Fumaz, 2018; Vanolo, 2016; Wiig, 2016), in practice, citizen participation is often synonymous with 'choice' and the market, with the predominant citizen roles being: 'consumer' or 'user', selecting which services to acquire from the marketplace of providers; 'resident', if they can afford the exclusive access to a smart district; or 'data product', creating data through their use of smart city technologies that companies can then incorporate into products and extract value from (Cardullo and Kitchin, 2019). 'Choice' reflects an ideal of neoliberal citizenship which promotes individual autonomy and freedom within defined constraints (as dictated by a particular set of rationalities related to capital accumulation, competitiveness, productivity, safety, security, etc.) that reproduce market-led provision of services. This ideal is further embedded in the everyday practices of 'smart citizens' as the design and functioning of computational devices have shifted 'users' of personal computers to 'consumers' of locational, real-time, cloud- and platform-based economies on the Internet (see Fuller, 2017).

In the following sections, we examine how citizens and citizenship are framed and operationalised through the discourse and programmes of a supra-national endeavour. The EIPSCC is an initiative of the EC, founded in 2011 with the aim of 'bringing together cities, industry, SMEs, banks, research and other smart city actors', 'boosting the development of smart technologies in cities' and 'improving citizens quality of life' by way of focusing on 'the intersection of Energy, ICT and Transport'. ${ }^{1}$ The EIP-SCC is divided into six clusters ${ }^{2}$ 
and a 'Marketplace'. Each cluster is composed of projects and commitments intended as 'measurable and concrete smart city engagements/actions from public and private partners'. According to its reports, there were 370 Commitments with over 4000 partners from 31 countries in June 2014. The Marketplace aims at providing the platform (a 'network of networks') through which cities and stakeholders can collaborate. The enterprise received initial funding of $€ 18$ million, which increased exponentially to $€ 365$ million only two years later, making it central to the EC policy goals of replication, emulation and translation.

It is our contention that the EIP-SCC seeks to corral and shape cities' 'wider extra-local fields of policymaking' (Peck et al., 2013: 1096; see also Brenner et al., 2010) by operating across places and scales in order to promote a technologically led neoliberal model of urban growth. Indeed, the 'Marketplace' aims to extend entrepreneurial urbanism and smart city policy through mimetic adaptation, scaling and replicating solutions to urban problems by funding initiatives across EU consortia that can develop working 'models' and 'best practices'. Its programme of 'Lighthouse Cities', for example, funds public-private applied research in small consortia of cities, with the ideas and initiatives developed then transferred to 'Follower Cities' in order to determine their wider applicability, adoption barriers, and how these might be ameliorated.

Part of the EIP-SCC mission is to consider modes of governance and the roles and functions expected of smart citizens. In the reminder of the paper, we examine the ideological underpinnings of the delivery, replication, and participation of most EIP-SCC 'citizenfocus' projects - those that claim to explicitly consider citizen roles rather than simply treat them as consumers or recipients of smart city initiatives. Our research consisted of three levels of data generation and analysis. First, we undertook a discourse analysis of policy documents and project descriptions of the 61 Commitments in the EIP-SCC 'citizen-focus' cluster. ${ }^{3}$ Second, we interviewed a dozen stakeholders working on citizen engagement in a small sample of EIP-SCC flagship projects, asking questions around the different institutional arrangements and scales in the delivery of their smart city projects, the time-line according to which their projects were prepared, funded, and institutionalized, and the actual existing spaces for citizen feedback and control within such projects. ${ }^{4}$ Third, we conducted 20 short and targeted interviews with city officers and corporate exhibitors at the 2017 Smart City Expo and World Congress (SCEWC), held annually in Barcelona. This is a professional, institutional and social meeting point, 'a leading platform of ideas, networking, experiences and international business deals', which in 2017 attracted over 18,000 visitors, with 675 exhibitors, from over 700 cities. ${ }^{5}$ The SCEWC is an important node in smart city policy and technology mobility, which during the year we attended also had its primary focus on the citizen.

Our different data points are set in the context of a smart city policy being mobilised at the scale of intra-city and European cooperation, but operationalised at the scale of the urban, the local, and the individual. First, following the 'trajectory' (Ward, 2010) that citizenship takes in these many smart city Commitments, we get a holistic picture of the symbolic and operational landscape of their conceptualisation, design, and implementation. The focus on trajectory is important as 'neoliberalisation denotes a direction rather than a destination' following 'a zigzagging path of creative destruction' (Peck and Whiteside, 2017: 181): that is, the local implementation of neoliberal policies is variegated and contradictory, whilst responding and adapting to the steering of supra-national and inter-urban policy objectives, networks, and funding regimes. Second, by following how the 'citizen' is operationalised in these smart city initiatives, we attend to the journey of policy from the transnational and relational context of the EC funding strategy to their interpretation, and eventual adaptation, in places. The relational approach we follow suggests that smart city 
policy and actions are 'brought and held together - assembled - by actors and institutions' across geographic scales (McCann and Ward, 2013). Neoliberal urbanism works, in fact, at a multi-scalar level creating a paradox for the neoliberal subject: as Wendy Brown (2016: 4) sums up, 'as neoliberal citizenship sets loose the individual to take care of itself, it also discursively binds the individual to the well-being of the whole'.

Therefore, the scope of this paper is neither to evaluate nor compare Commitments or Lighthouse cities performance in relation to their funded project descriptions. Further research would be needed to follow the 'actually existing' implementation of such policies in detail. Rather, the paper highlights the common ground and the scalar dimension through which these initiatives are put in place. As such, it unpacks the composite intertwining of policy objectives, funding provision, and discursive positioning of citizens within the technocratic agenda of neoliberal urbanism. In the next section, we set out briefly neoliberal urbanism and discuss smart citizenship and the 'right to the city' as a framework for our analysis of the EIP-SCC 'citizen focused' initiatives.

\section{The neoliberal smart city and smart citizenship}

Neoliberal urbanism can be summarised as a model of urban growth based on marketization, that is, the further 'subordination of place and territory to speculative strategies of profit-making at the expense of use values, social needs and public goods' (Peck et al., 2013: 1092). In a neoliberal framework, the market arranges services, infrastructure, and resources (including housing and public space) that hither-to-fore have been provided by the state. Such a shift in the ownership of what were public assets (privatisation) and provisioning of services (marketisation) has been driven by arguments concerning efficiency, competitiveness, and value-for-money that paved the way to strong austerity policies (Peck, 2012). Indeed, whilst visiting the SCEWC and talking to many private-sector representatives, engineers, and CEOs, it appeared clear to us that private companies are ultimately, if not exclusively, relying on public money to expand their smart initiatives. Mayors and city officials were seen overwhelmingly as customers, the smart interlocutors who are willing to invest in a problem-solving technology. Two complementary processes work to enable such a shift. First, cities struggling with tight budgets become increasingly reliant on competitive funding from supra-national bodies in order to implement technologies and services. Second, austerity is driving city administrations towards outsourcing and procurement of smart solutions that are purported as necessary to a city's own competitiveness (best practices among themselves) and as energy/labour-saving (best practices within themselves). At the same time, financial capital, increasingly central to innovation-led growth, has been strengthened through market re-regulation which protects short-term and risk-averse returns (Lazonick and Mazzucato, 2013), with cities being not just the sites of production and experimentation of technologies, but the ultimate target market (Rossi, 2017).

Smart cities, then, have emerged as the latest, tech-led phase of the entrepreneurial city (Hollands, 2008; Shelton et al., 2015), through which private interests seek to capture public assets and services by offering technological solutions to urban problems (e.g. congestion, emergency response, utility and service delivery). Dublin in Ireland illustrates this phasing, adopting ideas of entrepreneurial planning in the 1990s, the creative city discourse in the 2000s, and finally the smart city in the 2010s (Coletta et al., 2018; MacLaran and Kelly, 2014). Whilst setting appropriate goals for cities via systems of urban benchmarking, the neoliberal smart city aims to attract foreign direct investment, offering areas of the city as testbeds to pilot new technologies, fostering innovative indigenous start-up sectors or digital hubs, and attracting mobile creative elites. Intra-city competition fits well with a speculative 
approach to housing, privatisation of space, and attraction of more affluent buyers, all characteristics of neoliberal urbanism which conceives urban land via exchange value rather than use value (e.g. Kitchin et al., 2012).

Smart cities also extend and deepen neoliberal conceptions of citizenship. There is a vast interdisciplinary literature on citizenship per se, and urban citizenship more specifically. It is beyond the scope of the paper to extensively review the varying positions and debates and their evolution over time (see Burke Wood, 2017; Isin, 2000a; Smith and McQuarrie, 2012). Instead, we focus on the shift to neoliberal forms of urban citizenship, related arguments concerning the 'right to the city', and in particular on their manifestation in smart city discourses and initiatives.

In his classic text, Citizenship and Social Class (1950), Marshall denoted three sets of rights that define the citizenship status of citizens: civil/legal (e.g. right to own property, freedom of speech, liberty of the person, and the right to justice), political (e.g. right to vote and participate in the exercise of political power), and social (e.g. right to a certain level of economic welfare and security). To these rights, have been added cultural/symbolic rights that concern recognition, respect and protections with respect to identity (gender, race, sexuality, disability, faith, etc.). From this perspective, citizenship is 'a set of practices (cultural, symbolic and economic) and a bundle of rights and duties (civil, political and social) that define an individual's membership in a polity (usually a nation-state)' (Isin and Wood, 1999: 4).

In contrast, neoliberalism shifts citizenship away from inalienable rights and the common good towards a conception rooted in individual autonomy and freedom of 'choice', and personal responsibilities and obligations (e.g. Brown, 2016; Ong, 2006; Vanolo, 2016). Here, the onus is on the individual to navigate and negotiate the provision of services and levels of access, based on their personal social, political and economic capital, framed within 'commonsensical' constraints. As such, there is a re-orientation of citizenship towards market principles and the market acting as a 'means of regulating and coordinating the activities of numerous actors without direction from a single controlling centre' (Hindess, 2002: 140). As the work of city administrations are marketised, deregulated and privatised, the political and social aspects of citizenship likewise become transformed: instead of rights there are choices, with citizens framed increasingly as consumers.

In the neoliberal smart city, 'choice' is extended in space and time thanks to the proliferation of interconnected and location-aware devices. In practice, such devices are powered by corporate ecosystems such as Google-Android, Apple-iPhone or Amazon-Echo, made operational through contracts with private network providers, and exploited by vast transnational platform economies. Apparently free from legal interfaces and physical market boundaries, the entrepreneurial smart citizen is in constant search for affirmation and improvement (see also Brown, 2016; Ong, 2006). At the same time, critics suggest smart citizens are disciplined, nudged and controlled within new forms of governmentality - what Vanolo (2014) terms 'smartmentality' - enacted through technologies such as traffic management systems, control rooms, smart grids and meters, that seek to modulate behaviour and produce neoliberal subjects (Kitchin et al., 2017a). Smart technologies, in the forms of networked bodily and locational sensors and real-time big data streams, concur to the establishment of a neoliberal subject within the constraints of individual responsibility. Han (2017) calls this 'smartpolitics', arguing that whilst a politics of disciplining, punishing and perfecting the body was central to Foucault's notion of biopower, now neoliberalism has tapped into, and is exploiting, the psychic realm. This chimes with the notion that software is 'seductive' because it promises rewards for use, but at the same time it conditions through automation and forms of control (Kitchin and Dodge, 2011). With the coupling of 
personal and environmental sensor data with the affordances of digital networking technologies, smartness can lead to a 'gamification effect' which constitutes notions of 'good' or 'bad' citizen/user through disciplinary dispositives of ordering or ranking (Vanolo, 2018; see also Gabrys, 2014).

There are concerns that increased reliance on big data analytics, city-sensing, and socialmedia interactions, activated within a framework of technological solutionism, might privilege real-time and all-encompassing data- and algorithm-led planning decisions over political discussion and agonistic processes of governance (e.g. Kitchin, 2014). For critics, in fact, the dominant smart city discourse has been justifying a 'largely depoliticized ideological rubric' (Brenner and Schmid, 2015: 158), merging techno-scientific solutionism and ecological preoccupations as 'consensually agreed metaphors' (Swyngedouw, 2011, 2016) or 'stagemanaged consensus' (MacLeod, 2011). Even when smart city projects herald more effective forms of active citizenship and citizen empowerment - e.g. Living Labs, citizen-science and open source software - they often do so by co-opting citizen contribution into the wider economic landscape of efficiency, optimization, and a business-driven city (Cardullo et al., 2018; Perng et al., 2018). In other words, rather than fostering subversive ideals of experimentation, smart innovation appears more an exercise of replication via short-term and financially risk-averse projects (see also Lazonick and Mazzucato, 2013).

Such a neoliberal reframing of citizenship in the smart city jars with the emancipatory politics of the 'right to the city' as advocated by critics of neoliberalism. Henry Lefebvre (1996 [1967]) built his influential concept around the idea that citizens should not just have the right to occupy and use space, but that space should be shaped according to its inhabitants' needs (Purcell, 2002). As such, Lefebvre's ideal city is one that guarantees the right for inhabitants to participate fully in the production of urban space. For Isin (2000b: 14), the right to the city is 'the right to wrest the use of the city from the privileged new masters and democratise its space'. More recent extensions to the idea, important in the context of the smart city and its reliance on digital, networked technologies and the production and analysis of big data, are the 'right to the digital city' (de Lange and de Waal, 2013) and the 'informational right to the city' (Shaw and Graham, 2017). As Isin and Ruppert (2015) argue, given the ubiquitous nature of digital technologies in everyday life there is a need for digital citizens to possess a suite of digital rights. Indeed, as Attoh (2011) notes, the right to the (smart) city 'constitutes not a singular right, but a set of rights'.

It is thus both the production of neoliberal citizenship and its juxtaposition with the right to the city that we attend to in this paper. First, by questioning the way in which citizens are framed and operationalised within the neoliberal smart city agenda at European level. Second, using our critique of 'citizen-centric' smart city policies to recoup 'the political' in the sense suggested by Mouffe (1999): an agonistic struggle for hegemony where each contender recognizes the other's right to exist. We argue that the prevalent modes of governance in the neoliberal smart city today are rather discouraging agonistic spaces of political confrontation as they promote technological solutionism, underpinned by civic paternalism and stewardship, rather than more inclusive forms of citizen engagement and participation (Cardullo and Kitchin, 2019; Shelton and Lodato, 2019).

In the reminder of the paper, we consider the formation of the neoliberal subject and citizenship by examining the ideological underpinnings of delivery, replication, and participation of 'citizen-focus' projects within the EIP-SCC. We ask: how are citizens being conceived within the smart city, and who is the 'citizen-focused' smart city being built for? In so doing, we chart both the why and the how of policy transfer (McCann and Ward, 2013); how the smart city works as a multi-scalar and heterogeneous assemblage of neoliberal governance and why it has become a broadly accepted 'solution'. 


\section{The neoliberal smart city in the European Union}

Recent policy documents that conceptualise 'the smart city' put a lot of emphasis on shifting power to citizens, apparently addressing the critique that smart cities are overly state- and market-centric, rather than citizen-centric (Kitchin, 2015). For instance, the H2020 'Call for Smart and Sustainable Cities' expects funded projects to enhance 'citizen ownership of the solutions' through 'co-design, co-development and co-implementation of visionary urban planning' (European Commission, 2016: 116). The 'Co-Creating Smart Cities' report recommends "material or non-material rewards... to show users how important their collaboration in the projects is' (Citizen City Initiative EIP-SCC, 2016: 7). However, a closer analysis of 61 Commitments which have set their primary area as 'citizen-focus' reveals quite a different status of play. It would be impossible in this paper to evaluate these many projects individually, but we have reasonable room for mapping patterns in relation to two critical points, citizen participation and marketization. We divide the latter in three interrelated aspects: technological solutionism, nudging behaviour, and scaling and replication.

\section{Citizen participation}

The first point we observe is that these 'citizen-focus' projects score overwhelmingly in the lower categories on the 'scaffold of smart citizen participation' (Cardullo and Kitchin, 2019), with their initiatives realistically offering forms of tokenism (informing or consultation with feedback) or non-participation. In far too many cases, stakeholders of 'citizenfocus' projects offer a view of citizen participation limited to the free deployment of a smart meter, or to incentives for choosing energy efficient providers, or to parking issues relating to the 'how' and the 'where' of already decided deliverables for electric cars. In other words, the initiatives consist primarily of forms of stewardship and civic paternalism. Such a situation arises because the focus, objectives and solutions were set before problems and suggestions from citizens could be taken into account, an issue we observed across projects.

In part, this is because there has been little sustained grassroots attempts to create community-led smart cities and because of structural issues in producing a funding application. Putting together a large, multimillion euro bid is time-consuming and a complex task, carrying high financial or staffing overheads to facilitate a citizen-led bid. What this means is that in most cases, the only entities that can apply are government agencies, companies or universities. As a result, as of 2015, EIP-SCC partners in commitments were distributed: public authorities $36 \%$, business $26 \%$, academic/research institutions $16 \%$, others $14 \%$, and NGOs $6 \%$, with private individuals providing only $2 \%$ of all initiatives (EIP-SCC, 2015). Moreover, given the complexities of building a consortium of multiple stakeholders across several locations, adding 'non-expert' citizens into the mix is a significant additional overhead. Instead, the consortium makes a pitch for funding for a project that is designed to deliver certain outcomes (e.g. reduce energy or increase sustainable transport) and only when it has the funding in hand does it seek to engage with local communities.

You can't do the engagement before the project because obviously you don't have the funding. And what a lot of people don't realise is the type of engagement I am talking about is not like a quick consultation, a day or a week or a one event, it is a long deep conversation and relationship building that takes place over months... So the engagement part is where we shouldn't have set deliverables because it is about engaging the community and understanding the issues. [SC1] 
Any engagement that occurs after funding, even if designed to be citizen-centric, has then to meet pre-determined milestones and fulfil the deliverables of the contract, meaning citizens have limited scope to reframe the initiative around their concerns and desires. In a public meeting, we attended at one UK Lighthouse project, for instance, citizens questioned the already established targets for implementing electric cars as a substitute for traditional more polluting cars. Instead, they argued for measures to reduce the overall number of cars in their city. However, more than one project manager complained to us about the lack of flexibility for initiatives to change goals and project outlines or objectives:

There is too much translation between these big projects, with all their deliverables, and real people to make the connections; it is just really, really hard to do that in any way that reflects the real concerns of people, I think. [SC2]

As one project leader of a small 'citizen engagement' part in a much larger 'citizen-focus' project suggests: "what would make a huge difference is if funders had the confidence in an approach to allow responsiveness to community, to not have set goals' [SC5]. Instead, project objectives are vetted through 'a whole series of spreadsheets' with the predominance of quantitative indicators and benchmarks that appear at odd with the uncertainty of the innovation process and with its cumulative and collective character (see Lazonick and Mazzucato, 2013).

The EIP-SCC claims their Commitments 'move away from a traditional consultative approach towards a disruptive, non-conventional and pragmatic one... so citizens' voices are not only heard, but are instrumental in solution design' (EIP-SCC Action Cluster, 2015: 24). There is little evidence to support this assertion. In the smart city vision fostered by the EIP-SCC citizens are encouraged, at best, to help provide solutions to practical issues which would respond to local and contextual situations - these are forms of placation, such as producing an app during a hackathon, or feeding back on a development plan. They are not encouraged to formulate or lead initiatives or propose communitarian projects - such as sharing initiatives, or urban forms of co-ownership of the common good (e.g. co-ops or shared infrastructures). Neither are funding applicants asked to formulate an alternative to the fundamental political rationalities shaping an issue, or to re-imagine a political debate. In this sense, 'citizen-focus' is often just a buzzword to mollify critique that projects are too state- or market-led and to draw funding.

In our view, the paradox of fostering increased choice with less meaningful participation for citizens is due to the contradictory coming together of forms of technocratic and marketdriven governance with poorly understood and practised notions of conviviality, commoning, civic deliberation, resource sharing, trust building, and other face-to-face forms of confrontation and living that make polis and communities work. Whilst claiming to increase meaningful forms of direct participation, neoliberal governance works within structuring bureaucratic, technological and ideological path dependencies, and often hinges on computational forms of participation which are set already within circumscribed software environments and solutions (Gabrys, 2014; Kitchin et al., 2017a). This is often recognized by their own architects, as another project leader told us:

I am starting to think really there is too wide a gap between how these projects are working and the concerns and issues that real people are facing in their everyday lives. [SC9] 
As Wendy Brown (2016: 7) notes: 'In public life, governance displaces liberal democratic questions of justice with technical formulations of problems, and questions of right with questions of effectiveness; even questions of legality with those of efficacy'.

\section{Marketization of service provision}

If the central ethos of the core smart city intervention at European level, as set and operationalized by the EIP-SCC, is not really citizen empowerment or their control on the direction of urban change, we need to ask what are the real motivations and goals for setting up such a smart city programme for 'communities'? As suggested above, a politics of austerity (combined with EU law) pressures cities and other public institutions to privatize and outsource public provisions under the 'smart city' agenda. In the H2020 call for smart cities, this is recognised explicitly: one of the main forms of impact for initiatives seeking funding is to attract significant private investment in the delivery of public services. So we learn that a 'good impact' would be to show a reduction of 'the technical and financial risks in order to give confidence to investors for investing in large scale replication' (European Commission, 2016: 111), so that eventually 'private capital can take over further investments at low technical and financial risks' (European Commission, 2016: 108). In other words, there is an offer for the socialisation of risks in exchange for the privatisation of services and, eventually, profits. At times, the slippage between citizens, users, and consumers is evident: the H2020-SCC call suggests as a meaningful impact that the active participation of consumers must be demonstrated' (European Commission, 2016: 107, our emphasis). In contrast, we find only one mention of 'citizens' in the impact section, with the goal of making 'local energy system more secure, more stable and cheaper for the citizens and public authorities' (European Commission, 2016: 111, our emphasis). But what kind of 'citizen' is implied here? The installation of smart meters in their own home, or the incorporation of renewable energy source, hardly gives citizens/consumers an 'active participation' or a say in the running of the electricity company or grid. Rather, the citizen is a consumer in a marketplace of privatised utility provision and the product (as data). $\mathrm{S} / \mathrm{he}$ is useful to the extent to which s/he can produce revenue and valuable data for the company and for the deliverable of the Commitment itself. As such, even citizen engagement can become a 'lucrative and expanding business', as the CEO of a city platform app declared to us [SC10]. It is in this climate of increased marketization of citizens into consumers, users, and data-products that we need to frame citizen participation. In the following sub-sections, we discuss further three aspects of marketization and neoliberal governance with respect to 'citizen-centric' smart urbanism.

\section{Technological solutionism}

The smart city largely takes a technological solutionist approach to solving urban issues (Kitchin, 2014). That is, there is a presumption that all aspects of city functioning and life can be mediated or treated or optimized through technological solutions (Morozov, 2013). All that is required to solve issues such as congestion, energy consumption, emergency management of events, sub-optimal behaviour, and decision-making are data-driven software solutions. Unsurprisingly, we found a large number of city 'interfaces' working through apps and dashboards, generally utilising real-time data (public or not), aimed at 'solving' urban issues. For instance, Commitment 148 (SmartAppCity) promises a mobile application that integrates and presents all city services via a smartphone app aimed at 
'improving [citizens] quality of life and generating wealth' (ported in conjunction with a 'Geomarketing tool able to offer promotions and events to users who are close to their stores'). The Green Network promises to produce 'quantum energy savings, improve urban rent, quality of life and attractiveness of districts' and improve 'local and regional long term employment and growth' by refurbishing city districts with the 'latest materials and technologies'. Such an approach is underpinned by an instrumental rationality that largely divorces an issue from its wider framing, context and interdependencies, and the role of politics, governance, culture, and capital in shaping urban relations. Moreover, the operationalisation of these solutions are tracked and evaluated on a narrow range of measures. As a project leader on a Lighthouse initiative lamented:

Project leaders and the council are all ... like 'oh this is really important', but then all the meetings come back to: 'What are our deliverables? What are our measurable outputs? How do we achieve these measurable outputs?' Everything becomes about a spreadsheet at the end of the day. [SC2]

A key aspect of the narrative driving technological solutionism is that government is behind the technology curve with respect to state-of-the-art ideas and systems for managing cities, and that such solutions can only be delivered by the market as the public sector does not have sufficient knowledge, skills, resources or capacity to deliver or maintain them (Kitchin et al., 2017b). Instead, it needs to draw on the competencies held within industry (such as large global consultancies and the producers of software and hardware solutions) that possess sufficient expertise to guide city administrators and can deliver better city services through public-private partnerships, leasing, deregulation and market competition, or outright privatization (Shelton et al., 2015). The place of the public sector in this scenario is to challenge companies to offer solutions to a set of problems, to make resources available, facilitate stakeholder engagement, and manage contracts.

Technological solutions on their own are not, however, going to solve the deep rooted structural problems in cities as they do not address their root causes. Rather they only enable the more efficient management of the manifestations of those problems. For example, a technological solutionist approach to congestion is to produce an efficient traffic management system that seeks to optimize flow, or produce an app that directs drivers in real time as to what would be the quickest route given present traffic conditions. These solutions, however, do not address the deep structural issues underpinning congestion, which are infrastructural capacity and excessive demand. For instance, people attending the Lighthouse city meeting about electric cars suggested that the optimal and sustainable solution was to shift car use to walking, cycling and public transport. As such, whilst smart city technologies are promoted as the panacea for tackling urban problems, they largely paper over the cracks rather than fixing them, unless coupled with a range of political/social, public policy, and public investment solutions, and citizen-centred participatory democracy (Kitchin et al., 2017b).

\section{Nudging behaviours}

Parallel to this emphasis on technological solutionism, we observe the increasing trend of envisioning citizens as 'learners', with the aim of educating them as to how to best use resources or adopt a certain behaviour. The EC has set the key objective for smart cities as the 'transition towards a low carbon and resource efficient economy' - where urban EU populations are said to consume '70\% of our energy' (European Commission, 2016: 105). 
As this narrative suggests, the implementation of smart cities is a shared and urgent paradigm for our planet since it becomes ever-more urbanised. This has led to a cottage industry of apps which seek to educate and change behaviour, steering and nudging people towards an efficient model of urban growth that will simultaneously improve 'their quality of city life' (European Commission, 2016). Increasingly, public engagement and participation take the form of 'gamification' (see Vanolo, 2018). For instance, Clicks and Links ${ }^{6}$ is a company who promotes 'behavioural change through gaming and virtual reality' within CITY-ZEN, ${ }^{7}$ a project that aims to engage and educate citizens to energy-efficient infrastructures. On a similar vein, Commitment 6939 (Energy GOALS) wants to deliver an 'empowering game' aimed at 8-14 year old children to support behavioural change leading to an energy reduction in social housing. Commitment 7422 (Cooperative Gaming) offers a game on energy efficiency and the use of renewable energy between neighbourhoods within a metropolitan region and between different EU cities. Commitment 7788 (Mondragon commitment) too advocates the use of smart platforms and gaming to foster 'citizens behavioural change' for energy saving purposes and, in addition, offers the possibility for service providers 'to gather a quick picture of [citizens] current sentiment'.

Whilst one city official said she was seeing the 'already changing behaviour' of her fellow citizens recruited in a pilot project using smart meters pilot to reduce electricity consumption [SC8], some interviewees expressed deep concerns around the suitability of smart meters as indicators for a change of behaviour:

We have talked quite a lot about it [change of behaviour] and how we measure that. We need to look at the quantitative data that we might get from smart meters but we want to understand the everyday lives of some people we are working with. [SC6]

More focussed case studies it was argued will need to be carried out after projects have been delivered to get a true insight into how people understand and act with respect to energy consumption.

\section{Scaling and replication}

Scaling and replication are two crucial and interconnected issues at the heart of the smart city strategy at European level. Scaling seeks to bring forth 'best' solutions and translate successful pilots into deliverables. This strategy uses prototype pilot studies and in-situ trialling to produce market solutions that can be deployed elsewhere. In order to create confidence and a climate favourable to risk-taking investments, scaling aims 'to test and validate the business model' [SC8]. When funding for pilots ends, initiatives are vetted with respect to their sustainability with regards to the city and to 'the industrial partners and the industrial stakeholders that are also involved in a project, so they can see how they can replicate this in other areas and do business' [SC8]. That means that new service provisions are evaluated through efficiency criteria which, in the neoliberal austerity framework, translates necessarily into savings (doing more with less) of both physical and human resources and in the introduction of payment schemes in the medium term.

Replication is the process of translating scaled technologies and policies in other locales. Whilst scaling seeks to demonstrate local application, replication seeks to demonstrate generalisation and mobility; that smart city initiatives proven in one place can be deployed with similar results elsewhere. It is through this process that transferable technologies, models or 'best practices' and their circulation are established (McCann and Ward, 2011). In the case of EIP-SCC, this occurs through the Marketplace: Lighthouse cities work together to pilot 
and scale initiatives before Follower cities seek to replicate their work with the aim of creating a feedback loop that can inform the initial deployment, as well as create a case for wider deployment. But replication presents a circular rationale. The Lighthouse status is 'itself the product of discursive attribution' through which applicant cities have been awarded, and thus certified by the EC, as being 'outstanding' smart cities (Engelbert et al., 2019). At the same time, Commitments are projects which endorse an already specific version of the smart city: for instance, Commitment 7388 (Ravenna Common Ground) advances a 'device aimed at providing the community [with] a reinforcement in a smart perspective'. Commitment 7283, 'The Educating City', wants to develop 'interoperable platforms and devices ... to provide support to the objectives set up by EIP's Strategic Implementation Plan regarding citizens' involvement and their awareness'.

The circularity between smartness as the 'fix' to city problems and its spinning mechanism is here evident. But as we have been told, 'certain private and public partners have had to change their offering in order for it to be replicable after the funding has finished' [SC8]. In other words, the initiative produced technologies or policies that were only partially transferable. This is because neoliberalism comes in a variety of means, shaped by national and local political economies, political ideology, state policies, institutional cultures, market practices, legal frameworks, and public sentiment (Brenner et al., 2010). Neoliberalism is a 'mutable, inconsistent, and variegate process' (Springer, 2012: 135), it does not operate in all places at all times in a unified, universal manner, but has varying stages, topographies and topologies (O'Callaghan et al., 2015). Thus, the way in which funding provisions and practices are set suggests little manoeuvrability with the messiness of city living, with project managers sometimes resolving to 'promising practices'. As one project leader admits [SC1]: 'The project as a whole can run because you've said to the funders, in order to get your funding, "these are the things that we are going to achieve"; but sometimes you don't know that'.

Whilst citizens might be stakeholders in the initial urban experimentation, and perhaps in replication studies, it is unlikely they are consulted once the initiative reaches the stage of market product. Instead, the product is made openly available to the market in the case of apps, or procured or adopted by city technocrats on behalf of citizens in the case of infrastructure and policy. Indeed, as Kitchin et al. (2017b) note, in many cases neither citizens nor politicians are involved in smart city deployments such as smart lighting, parking and sensor networks, which are considered operational matters and often fall outside of direct political oversight. In this sense, the initiatives are only citizen-focused at particular stages, but not throughout the life cycle of development and deployment.

\section{Towards a different kind of smart city}

During our fieldwork, we met many young and enthusiast officers, developers, and community engagement advocates who supported the smart city vision and without doubt are doing their best to slot digital technologies into the everyday life of cities in ways that improve citizens' lives. For us, a key issue is that they work forcibly within a neoliberal framework that underpins their initiatives: through the framework of the EC funding schemes and the process by which projects are conceived, evaluated and delivered, neoliberal ideals are transmitted in detail and modelled on the dogmas of efficiency (saving scarce energy), sustainability (changing policy orientation in the long term), and freedom of choice (although instrumental to market imperatives). Our analysis has highlighted the extent to which EIP-SCC works as a mechanism of adjustments of opportunities and a platform 
which allocates funding, displays pre-packaged solutions for various stakeholders, and favours exchanges within already determined boundaries of cooperation. We individuated three specific forms of governance through which this process of marketization takes place: technical solutionism, nudging behaviour, and scaling/replication. Ultimately, we contend the supra-national strategy for 'citizen-focused' smart cities acts as a smokescreen to a much more deliberate neoliberal agenda for cities whilst circumscribing a particular role for their citizens.

For us, the limited forms of citizen engagement and citizen power enacted within smart city initiatives means that we need to re-imagine what it means to be a 'smart citizen'. This requires moving beyond neoliberal conceptions of citizenship, in which people act as consumers or users within a marketplace of services, and beyond initiatives created through stewardship and civic paternalism (in which elites decide what is best for all). Instead, an alternative vision of smart cities and citizenship needs to be adopted, one that has a number of characteristics drawn from the 'right to the city' debate.

First, the smart city would be orientated towards reflecting and serving the interests of citizens, rather than these continuing to be subservient to the interests of state and market. Second, there would be a more inclusive and deliberative framing of citizen participation in the smart city beyond consumerism and tokenistic civic engagement, including more extensive public consultation, collaboration and co-production, and roles such as creators, members and leaders, as well as initiatives gaining more input and oversight by elected officials. Third, there would be a shift back from citizenship grounded primarily in market principles to a framework underpinned by a set of civil, social, political, symbolic and digital rights and entitlements. Fourth, public assets would form commons to be protected and leveraged for the common good. Fifth, rather than smart city initiatives being directed principally at instrumental issues, more normative concerns such as fairness, equity, democracy, and social justice would become centre-stage. From this perspective, citizens and civility would be at the core of smart city initiatives, rather than capital and the market.

Although we could not find such a configuration in existing EIP-SCC funded projects, we have been looking with increasing interest at the political and social developments in the Barcelona's smart city programme. Under a right-wing government, Barcelona was a blueprint for neoliberal smart urbanism, partnering with multinationals such as CISCO, and performing various smart city initiatives with aggressive self-promotion, as well as initiating the SCEWC to promote smart cities more globally (March and Ribera-Fumaz, 2016). Since May 2015, however, guided by Ada Colau - a long-time activist with respect to housing and wealth equality (see Colau and Alemany, 2012) - and by a sustained grass-root political movement (Barandiaran et al., 2017), there has been a new political and organisational approach to smart cities. This has included making smart city initiatives much more citizen-centric and participatory, adopting the concept of 'technological sovereignty' as a new form of citizenship, and appointing a new commissioner of Technology and Digital Innovation. Technological sovereignty is the notion that technology should be orientated to and serve local residents, and be owned as a commons, rather than applying a universal, market-orientated, proprietary technology (Galdon, 2017). As explained by the Deputy Mayor of Barcelona:

In a democratic city, technology should serve to digitally empower citizens, to protect their privacy from abuses by the public and private powers, to fight against corruption and to advance towards a more equitable and sustainable economy. That has a name: conquering technological, digital sovereignty, for the common good. (quoted in Galdon, 2017) 
Here, there is a commitment to using open source technologies and to retaining ownership and control of data infrastructure whilst guaranteeing access for citizens (Galdon, 2017). A new set of experiments with open data, control of personal data, civic apps, and crowdsourced sensors are connecting citizens (some more than others) to technology without curtailing their rights and entitlements, with the aim of combining a 'digital revolution with democratic revolution' (see Barandiaran et al., 2017; Bria, 2017; March and RiberaFumaz, 2018). Further, service provision (electricity and water) is being municipalised and there are experiments with universal basic income and forms of rent control (e.g. the development of an on-line map and register of vacant properties and forms of rent control through a FairBnB pilot, in order to improve the supply of affordable housing).

Barcelona has thus sought to re-politicize the smart city and to shift its creation and control away from private interests and the state towards citizens and communities, civic movements and social innovation. An important part in the organisation of this politics has been Decidim, 'a digital infrastructure for participatory democracy, a "public-common" project mostly financed and made possible by the city, but managed and designed by an open community' [SC7]. According to one of the main architects of this project, who we interviewed during SCEWC 2017 in Barcelona, Decidim is changing the terms of governance, making it much more transparent and participatory:

The city council decides that a topic, for instance a new regulation or a mobility plan, is going to be done with the citizens. And then it opens up a participatory process on the digital platform and beyond. And then we have 'the result', an agreement, maybe it is a 20 page plan or a new regulation with 80 articles. [SC7]

Importantly, the participatory phase involves an active consultation process: for instance, over 700 public meetings were organised around the strategic planning initiatives since:

We don't think digital participation exists. So, Decidim is not only about political participation through digital means; it is also to reflect on the rest of the participation, the physical encounters and the results of them, and to digitalise them on the platform. [SC7]

For us, Barcelona's attempt to re-envisage the smart city around technological sovereignty offers a different form of smart citizenship, one much more grounded in the hopes and politics of the 'right to the city' agenda. Indeed, Barcelona's new smart city vision, includes the foundational elements of cohesiveness and fairness we envision for a 'communal smart city', extending the role of citizens well beyond data-points and consumers and potentially producing a social collective rather than a society of interconnected individuals. As such, Barcelona's new policy seems to point to an attempt to enact the 'right to the smart city'; a right of inclusion and participation for the many rather than the few. It is an approach that is in stark contrast to that envisaged by the EIP-SCC as presently conceived, but one that offers pointers for how smart cities in Europe and elsewhere might be productively re-orientated.

\section{Declaration of conflicting interests}

The author(s) declared no potential conflicts of interest with respect to the research, authorship, and/or publication of this article. 


\section{Funding}

The author(s) disclosed receipt of the following financial support for the research, authorship, and/or publication of this article: The research for this paper was funded by an ERC Advanced Investigator award, 'The Programmable City' (ERC-2012-AdG 323636-SOFTCITY).

\section{ORCID iD}

Rob Kitchin (D) http://orcid.org/0000-0003-4458-7299

\section{Notes}

1. https://eu-smartcities.eu/

2. These are: 'citizen focus'; 'business models, finance and procurement'; 'integrated infrastructure and processes'; 'integrated planning, policy and regulations'; 'sustainable districts and built environment'; and 'sustainable urban mobility'. https://eu-smartcities.eu/clusters

3. It is important to note that the EIP-SCC portal has undergone a complete overhaul since our initial research, making it difficult to locate the original details for each Commitment - although see a limited list at: https://eu-smartcities.eu/commitments. Much of the original Commitments are no longer publicly available and we can only refer readers to the list of Commitments archived by the 'Way Back Machine' - http://web.archive.org/web/20170416191724/https://eu-smartcities.eu/com mitments. This is in itself troubling given the 'citizen-focus' cluster's supposed ethos of data openness, democratic governance, and public engagement.

4. Interviews were conducted in two European cities in October and November 2017.

5. www.smartcityexpo.com/en/

6. http://clicksandlinks.com/dvteam/city-zen/

7. www.cityzen-smartcity.eu/home/about-city-zen/calendar/

\section{References}

Arnstein SR (1969) A ladder of citizen participation. Journal of the American Institute of Planners 35(4): 216-224.

Attoh KA (2011) What kind of right is the right to the city? Progress in Human Geography 35(5): 669-684.

Barandiaran X, Calleja A, Monterde A, et al. (2017) Decidim: Redes políticas y tecnopolíticas para la democracia participativa. RECERCA. Revista de Pensament i Anàlisi 21: 137-150.

Brenner N and Schmid C (2015) Towards a new epistemology of the urban? City 19(2-3): 151-182.

Brenner N and Theodore N (2002) Cities and the geographies of "actually existing neoliberalism". Antipode 34(3): 349-379.

Brenner N, Peck J and Theodore N (2010) Variegated neoliberalization: Geographies, modalities, pathways. Global Networks 10(2): 182-222.

Bria F (2017) Reclaiming Europe's digital sovereignty. Available at: www.acast.com/ft-tech-tonic/ reclaimingeuropesdigitalsovereignty (accessed 30 October 2017).

Brown W (2016) Sacrificial citizenship: Neoliberalism, human capital, and austerity politics. Constellations 23(1): 3-14.

Burke Wood P (2017) Citizenship, Activism and the City. London: Routledge.

Cardullo P and Kitchin R (2019) Being a 'citizen' in the smart city: Up and down the scaffold of smart citizen participation in Dublin, Ireland. GeoJournal 84(1): 1-13.

Cardullo P, Kitchin R and Di Feliciantonio C (2018) Living labs and vacancy in the neoliberal city. Cities 73: 44-50.

Citizen City Initiative EIP-SCC (2016) Co-creating smart cities. Available at: http://archive.eu-smartc ities.eu/content/citizen-city (accessed 9 February 2018). 
Colau A and Alemany A (2012) Mortgaged lives: From the housing bubble to the right to housing. Los Angeles: Journal of Aesthetics and Protest Press. Available at: http://www.joaap.org/press/ pah/mortgagedlives.pdf (accessed 18 February 2018).

Coletta C, Heaphy L and Kitchin R (2018) From the accidental to articulated smart city: The creation and work of 'Smart Dublin'. European Urban and Regional Studies, pp. 1-16. Epub ahead of print 13 July 2018. DOI: 10.1177/096977641878521.

Cowley R, Joss S and Dayot Y (2018) The smart city and its publics: Insights from across six UK cities. Urban Research \& Practice 18(1): 53-77.

Datta A (2018) The digital turn in postcolonial urbanism: Smart citizenship in the making of India's 100 smart cities. Transactions of the Institute of British Geographers 43(3): 405-419.

de Lange M and de Waal M (2013) Owning the city: New media and citizen engagement in urban design. First Monday 18(11). Available at: http://firstmonday.org/ojs/index.php/fm/article/view/ 4954 (accessed 1 February 2017).

EIP-SCC (2015) Invitation for Commitments. Brussels: European Commission.

EIP-SCC Action Cluster (2015) Principles and enablers for citizen engagement: the experience from the EIP-SCC. Available at: http://www.remourban.eu/kdocs/1229105/ Principles_and_enablers_for_citizen_engagement.pdf (accessed 8 October 2018).

Engelbert J, van Zoonen L and Hirzalla F (2019) Excluding citizens from the European smart city: The discourse practices of pursuing and granting smartness. Technological Forecasting and Social Change 142: 347-353.

European Commission (2016) Horizon 2020 Work Programme 2016-2017. 17, Cross-cutting activities (Focus Areas) No. 17. https://ec.europa.eu/research/participants/data/ref/h2020/wp/2016_2017/ main/h2020-wp1617-focus_en.pdf (accessed 9 February 2018)

Foth M, Brynskov M and Ojala T (2015) Citizen's Right to the Digital City: Urban Interfaces, Activism, and Placemaking. Singapore: Springer.

Fuller M (ed) (2017) How to Be a Geek: Essays on the Culture of Software. Cambridge: Polity.

Gabrys J (2014) Programming environments: Environmentality and citizen sensing in the smart city. Environment and Planning D: Society and Space 32(1): 30-48.

Galdon G (2017) Technological Sovereignty? Democracy, Data and Governance in the Digital Era. CCCB Lab. Available at: http://lab.cccb.org/en/technological-sovereignty-democracy-data-andgovernance-in-the-digital-era/ (accessed 6 April 2018).

Han B-C (2017) Psychopolitics: Neoliberalism and New Technologies of Power. Brooklyn: Verso Books.

Hindess B (2002) Neo-liberal citizenship. Citizenship Studies 6(2): 127-143.

Hollands RG (2008) Will the real smart city please stand up? Intelligent, progressive or entrepreneurial? City 12(3): 303-320.

Isin EF (2000b) Introduction. In: Isin EF (ed) Democracy, Citizenship and the Global City. London: Routledge, pp.1-21.

Isin EF (ed) (2000a) Democracy, Citizenship, and the Global City. London: Routledge.

Isin EF and Ruppert E (2015) Being Digital Citizens. London: Rowman \& Littlefield.

Isin EF and Wood PK (1999) Citizenship and Identity. London: SAGE.

Kitchin R (2014) The real-time city? Big data and smart urbanism. GeoJournal 79(1): 1-14.

Kitchin R (2015) Making sense of smart cities: Addressing present shortcomings. Cambridge Journal of Regions, Economy and Society 8(1): 131-136.

Kitchin R and Dodge M (2011) Code/Space: Software and Everyday Life. Cambridge, MA: MIT Press.

Kitchin R, Coletta C and McArdle G (2017a) Urban informatics, governmentality and the logics of urban control. Programmable City Working Paper 25. Available at: https://osf.io/preprints/socar xiv/27hz8/ (accessed 7 June 2018).

Kitchin R, Coletta C, Evans L, et al. (2017b) Smart cities, epistemic communities, advocacy coalitions and the 'last mile' problem. IT - Information Technology 59(6): 275-284.

Kitchin R, O'Callaghan C, Boyle M, et al. (2012) Placing neoliberalism: The rise and fall of Ireland's Celtic Tiger. Environment and Planning A 44(6): 1302-1326. 
Lazonick W and Mazzucato M (2013) The risk-reward nexus in the innovation-inequality relationship: Who takes the risks? Who gets the rewards? Industrial and Corporate Change 22(4): 1093-1128.

Lefebvre H (1996) Writings on Cities. Cambridge, Mass: Blackwell.

Lombardi P and Vanolo A (2015) Smart city as a mobile technology: Critical perspectives on urban development policies. In: Rodríguez-Bolívar MP (ed) Transforming City Governments for Successful Smart Cities. Amsterdam: Springer, pp.147-161.

MacLaran A and Kelly S (2014) Irish neoliberalism and neoliberal urban policy. In: MacLaran A and Kelly S (eds) Neoliberal Urban Policy and the Transformation of the City. London: Palgrave Macmillan, pp.20-36.

MacLeod G (2011) Urban politics reconsidered: Growth machine to post-democratic city? Urban Studies 48(12): 2629-2660.

March H and Ribera-Fumaz R (2016) Smart contradictions: The politics of making Barcelona a selfsufficient city. European Urban and Regional Studies 23(4): 816-830.

March H and Ribera-Fumaz R (2018) Barcelona: From corporate smart city to technological sovereignty. In: Karvonen A, Cugurullo F and Caprotti F (eds) Inside Smart Cities: Place, Politics and Urban Innovation. London: Routledge, pp.229-243.

Marshall TH (1950) Citizenship and Social Class. Cambridge: Cambridge University Press.

McCann E and Ward K (2011) Mobile Urbanism: Cities and Policymaking in the Global Age. Minneapolis: University of Minnesota Press.

McCann E and Ward K (2013) A multi-disciplinary approach to policy transfer research: Geographies, assemblages, mobilities and mutations. Policy Studies 34(1): 2-18.

McLaren D and Agyeman J (2015) Sharing Cities: A Case for Truly Smart and Sustainable Cities. Cambridge: MIT Press.

Morozov E (2013) To save Everything, Click Here: Technology, Solutionism, and the Urge to Fix Problems That Don't Exist. London: Penguin.

Mouffe C (1999) Deliberative democracy or agonistic pluralism? Social Research 66(3): 745-758.

O'Callaghan C, Kelly S, Boyle M, et al. (2015) Topologies and topographies of Ireland's neoliberal crisis. Space and Polity 19(1): 31-46.

Ong A (2006) Mutations in citizenship. Theory, Culture \& Society 23(2-3): 499-505.

Peck J (2012) Austerity urbanism: American cities under extreme economy. City 16(6): 626-655.

Peck J and Whiteside H (2017) Neoliberalizing Detroit. In: Schram SF and Pavlovskaya M (eds) Rethinking Neoliberalism: Resisting the Disciplinary Regime. London: Routledge, pp.179-196.

Peck J, Theodore N and Brenner N (2013) Neoliberal urbanism redux? Debates. International Journal of Urban and Regional Research 37(3): 1091-1099.

Perng S-Y, Kitchin R and MacDonncha D (2018) Hackathons, entrepreneurship and the making of smart cities. Geoforum, pp. 1-9. Epub ahead of print September 2018. DOI: 10.1016/j. geoforum.2018.08.024.

Purcell M (2002) Excavating Lefebvre: The right to the city and its urban politics of the inhabitant. GeoJournal 58(2): 99-108.

Rossi U (2017) Cities in Global Capitalism. Chichester: John Wiley \& Sons.

Shaw J and Graham M (2017) An informational right to the city? Code, content, control and the urbanization of information. Antipode 49(4): 907-927.

Shelton T and Lodato T (2019) Actually existing smart citizens: Expertise and (non)participation in the making of the smart city. City, pp. 1-8. Epub ahead of print 5 February 2019. DOI: 10.1080/ 13604813.2019.1575115.

Shelton T, Zook M and Wiig A (2015) The 'actually existing smart city'. Cambridge Journal of Regions, Economy and Society 8(1): 13-25.

Smith PS and McQuarrie M (eds) (2012) Remaking Urban Citizenship: Organizations, Institutions and the Right to the City. London: Routledge. 
Springer S (2012) Neoliberalism as discourse: Between Foucauldian political economy and Marxian poststructuralism. Critical Discourse Studies 9(2): 133-147.

Swyngedouw E (2011) Interrogating post-democratization: Reclaiming egalitarian political spaces. Political Geography 30(7): 370-380.

Swyngedouw E (2016) The mirage of the sustainable 'smart' city. Planetary urbanization and the spectre of combined and uneven apocalypse. In: Nel-Lo O and Mele R (eds) Cities in the 21st Century. London: Routledge, pp.134-143.

Vanolo A (2014) Smartmentality: The smart city as disciplinary strategy. Urban Studies 51(5): 883-899.

Vanolo A (2016) Is there anybody out there? The place and role of citizens in tomorrow's smart cities. Futures 82: 26-36.

Vanolo A (2018) Cities and the politics of gamification. Cities 74: 320-326.

Ward K (2010) Towards a relational comparative approach to the study of cities. Progress in Human Geography 34(4): 471-487.

Wiig A (2016) The empty rhetoric of the smart city: From digital inclusion to economic promotion in Philadelphia. Urban Geography 37(4): 535-553.

Paolo Cardullo is a postdoctoral researcher at The Programmable City at NIRSA, Maynooth University, Ireland. Previously, He was previously an Associate Lecturer at Sociology, Goldsmiths, University of London, where he defended his $\mathrm{PhD}$ in October 2013. He has published and peer-reviewed for numerous journals: more info and publications from kiddingthecity.org

Rob Kitchin is a professor in the Maynooth University Social Sciences Institute and principal investigator of The Programmable City and Building City Dashboards projects. He is the author/editor of 28 books and the editor of the journal, Dialogues in Human Geography. 